\title{
Voice Analysis as a Follow Up Tool on Reinke's Edema
}

\author{
Abdoerrachman $\mathrm{H}^{*}$, Imaizumi $\mathrm{S}^{* *}$, Kiritani $\mathrm{S}^{\star *}$, Niimi $\mathrm{S}^{\star \star}$, Hirose $\mathrm{H}^{\star *}$, Yonekawa $\mathrm{H} .{ }^{* \star *}$
}

\begin{abstract}
Abstrak
Telah dilakukan suatu penelitian terhadap kualitas suara pra dan pascaterapi dengan menganalisa sampel suara dari 35 penderita edema Reinke pada pita suara. Dari beberapa karakteristik suara yang diekstraksi, hasil yang didapat adalah kenaikan yang bermakna dari frekuensi dasar (FO), serta penurunan yang konstan dari dimensi fraktal FO, bising suara, kekacauan suara, variabilitas kekacauan suara, enersi dari kekacauan lambat dan cepat, dengan dominasi yang menetap pada penderita wanita. Variabilitas, stabilitas serta keteraturan suara pascaterapi pada penderita-penderita tersebut membaik secara bermakna. Penelitian ini menunjukkan bahwa metoda analisa akustik berguna sebagai alat tindak lanjut untuk evaluasi kuantitatip perubahan suara pasca tindakan.
\end{abstract}

\begin{abstract}
Voice qualities pre and post treatment were studied by analyzing sustained vowel voice samples of 35 parients with Reinke's edema. Results obtained from extracted voice properties were statistically significant increase in mean fundamental frequency, a constant decrease in fractal dimension of fundamental frequency and amplitude, the additive noise level, jitter and shimmer, the overall variability, the energy of slow and fast perturbation, with incessant female dominance. It was concluded that the variability, regularity, and stability of the post treatment patients voices are improved. The results indicate that the acoustical analyzing method is an advantageous monitoring tool for quantitative evaluation of vocal changes post treatment.
\end{abstract}

Keywords: Voice quality, Acoustical assessment, Reinke's Edema

\section{INTRODUCTION}

There has been a growing active interest in objective documentation and assessment of voice quality. This interest has occured because of the important advances in techniques and analysis that can be applied to vocal physiology in a scientific manner. Clinicians have recently explored the usefulness of various acoustic factors of vocal fold vibrations.

When a patient complains of hoarseness, an important clinical decision must be made whether it is a pathological or a functional symptom. This decision will influence directly the mode of treatment, and so any objective methods for supporting treatment decisions, if they can be made automatic, reliable, cost effective and non-invasive, are obviously of otolaryngological value.
According to Laver ${ }^{1}$ there are four major applications of automatic methods of perturbation analysis that could identify persons with laryngeal pathology, and one of those is as a follow up tool. A monitor to assess voice changes after the patients received treatment, also to detect remission or deterioration in progressive diseases.

Some authors had reported sach investigations, e.g. Imazumi ${ }^{2}$ and Yonekawa ${ }^{3}$ who conducted investigations of acoustical and vocal changes on Reinke's edema. Despite the many studies that had been reported, further frugal exploration on the characteristics of voice changes are still advantageous.

In the present study, the variability, regularity and the stability of the patient's voice post-operatively are determined, and speculations on factors and source of

\footnotetext{
* Center of Ear Care and Communicative Disorder, Department of Otorhinolaryngology, Faculty of Medicine, University of Indonesia, Jakarta, Indonesia.

** Research Institute of Logopedies and Phoniatries, Faculty of Medicine, University of Tokjo, Tokyo, Japan.

*** Department of Otolaryngology, Kinki University School of Medicine, Osaka, Japan.
} 
voice changes that cause the acoustical alterations will be discussed as well.

\section{MATERIALS AND METHODS}

The subjects for this study were 35 patients with various grade of severity of Reinke's edema (polypoid of vocal cord) diagnosed and treated in the ENT Department Kinki University School of Medicine, Osaka, and voice samples were recorded before and after treatment in the follow up.

Using DAT tape-recorder, recordings were made with a constant distance from mouth to microphone of $15 \mathrm{~cm}$, following patients practice and were made in a sound treated booth. Voice samples of sustained vowel /e/ were digitized through a 12-bit A/D converter at a sampling rate of $40 \mathrm{kHz}$ and stored on a disk controlled by a computer. A half-second segment was extracted by excluding the initial and final portion from each sample.

Using peak picking method, recommended by Imaizumi, ${ }^{4,5}$ local maximum points which could correspond to vocal excitation epochs were detected successively, and then the fundamental frequency $F_{0}$ ( i ) and the maximum amplitude $A(i)$ of $i$-th glottal period were determined. Several parameters were extracted and calculated such as mean fundamental frequency
$(\mathrm{Hz})$, fractal dimension of $\mathrm{F}_{0}(\mathrm{i})$ and $\mathrm{A}(\mathrm{i})$, the additive noise level (dB), the PPQ (\%) and APQ (\%), the overall variability, the $F_{0}$ and Amp. fluctuation frequency, low and high frequency energy in $F_{0}(i)$ and A (i) normalized by DC level (dB). The meaning and the detail of the method and definitions had been decribes in the previous papers by Imaizumi, ${ }^{5}$ and Abdoerrachman. ${ }^{\circ}$

Student t-tests for paired samples were applied to determine significance between pre and post-treatment, for both sex groups.

\section{RESULTS}

Since the aim of the investigation is to illustrate the benefit of acoustical assessment as a monitoring tool, all the configurations will be projected in the difference of the magnitude scores pre and post operatively, in box whisker graphs with the statistical calculation enclosed.

The present study showed the following results. Figure 1 showed the box-whisker graph of the difference of mean F0 pre and post-treatment for both sex groups. Female group showed larger variance, with higher score of difference. Statistical calculation for paired t-test indicated significant difference for pre and post treatment both sex groups (M: $\mathrm{p}<0.004$ and $\mathrm{F}$ : $\mathrm{p}<0.007$ ).

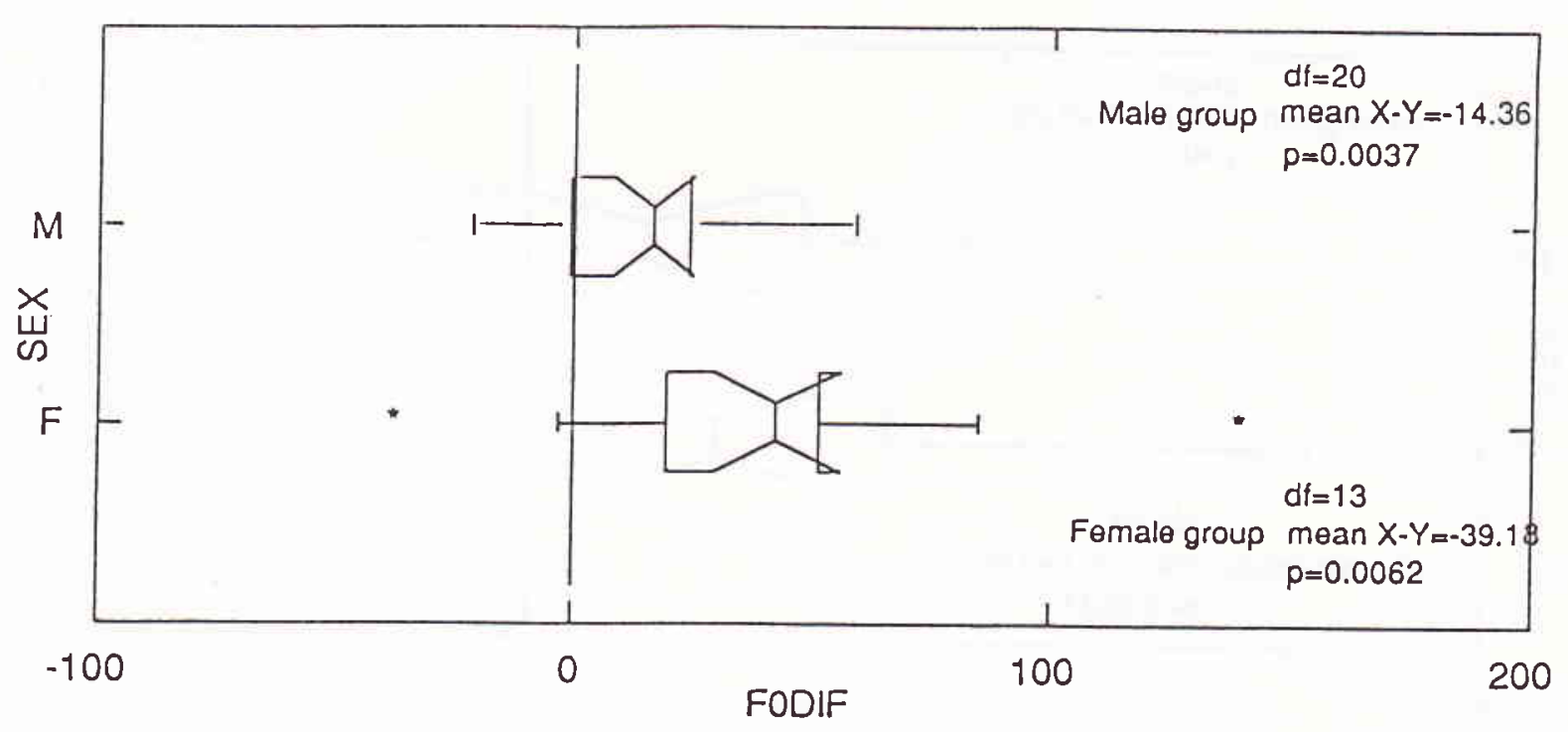

Figure 1 
Figure 2 showed the difference of fractal dimension of F0 pre and post-treatment for both sex groups, indicating the decrease of chaotic condition, although both were not statistically significant.
Figure 3 showed the difference of the Pitch Perturbation Quotient (PPQ) pre and post-treatment for both sex groups, indicating decrease of PPQ postoperatively, with female had larger decrement. (M: $p<0.05$ and $F: p<0.003)$.

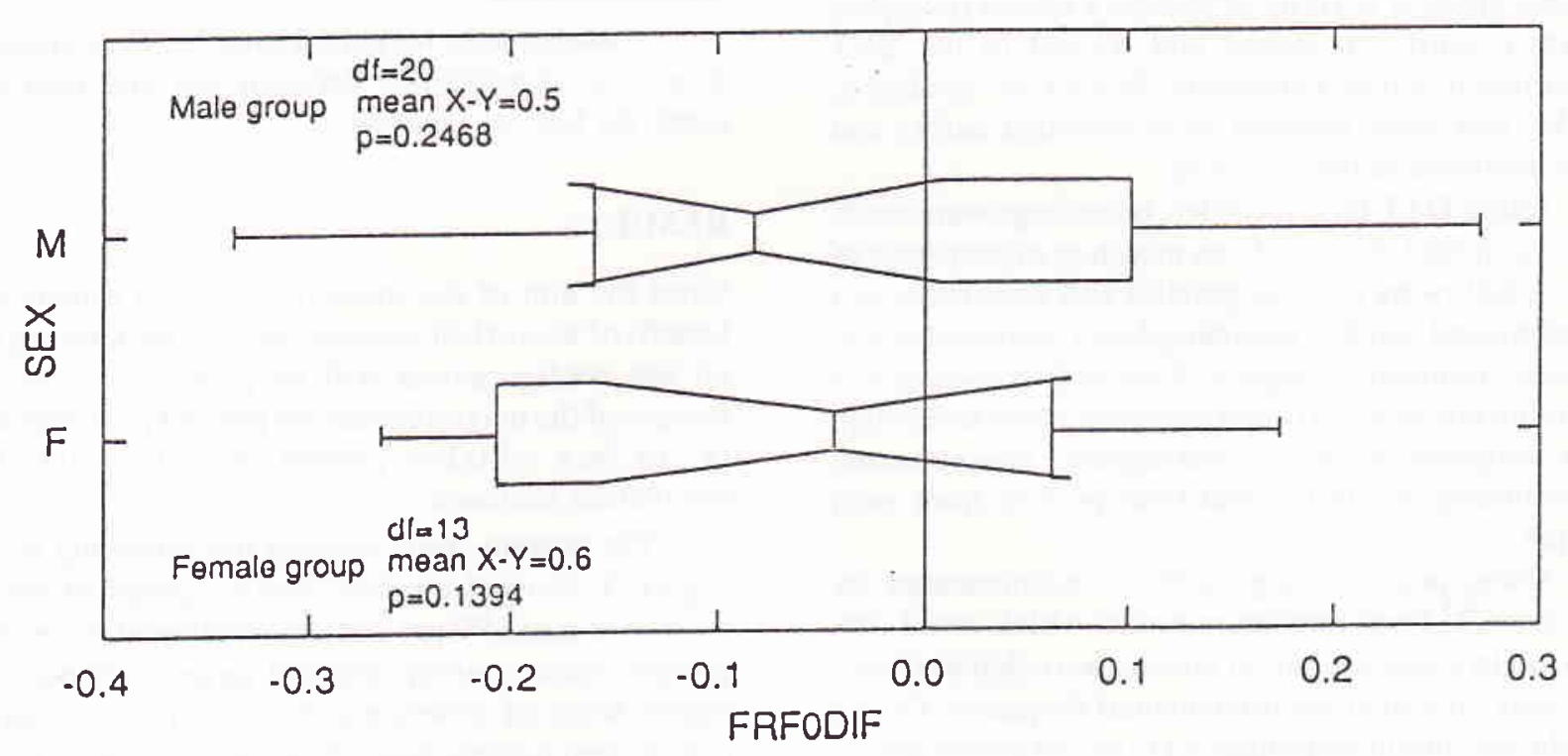

Figure 2

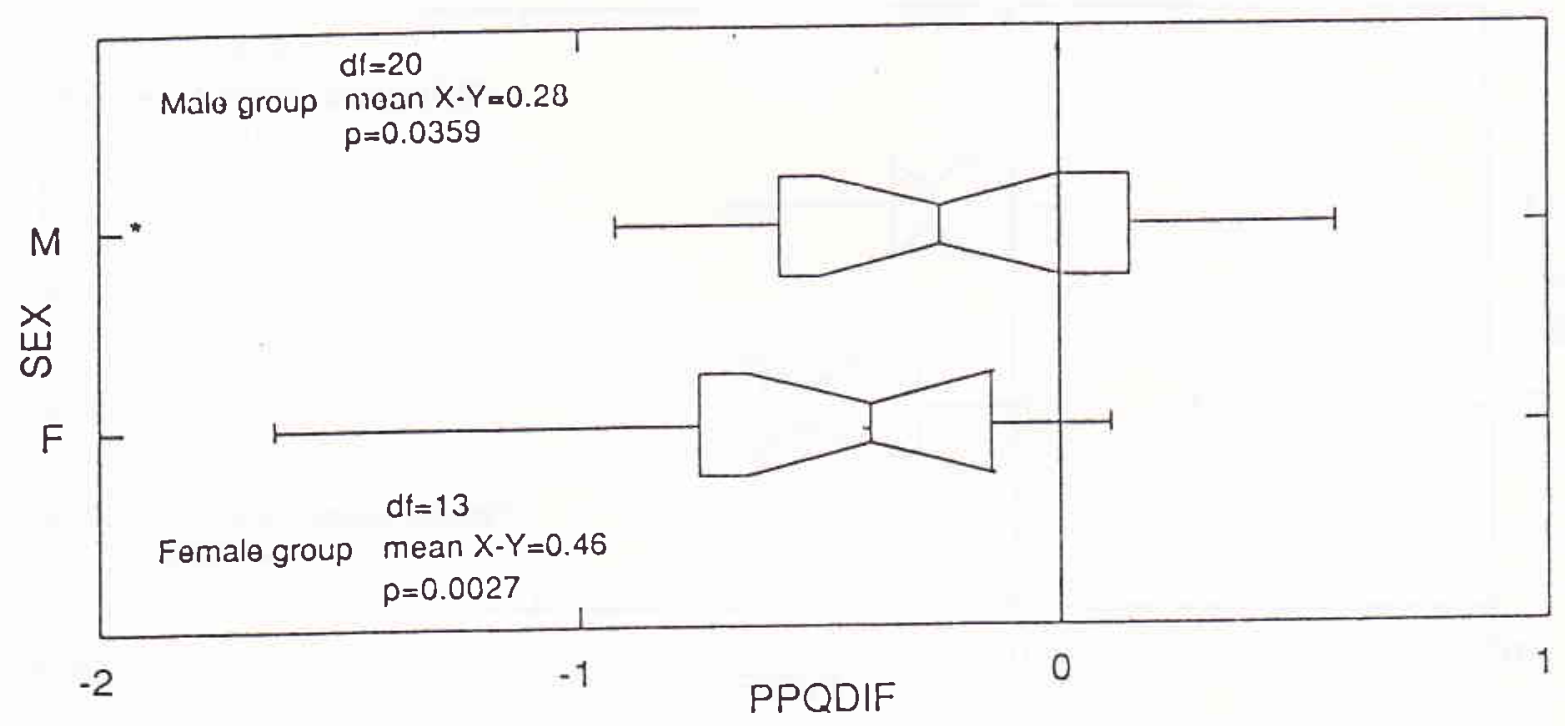

Figure 3 
Figure 4 showed the difference of the Additive Noise Level (NLvl) pre and post-treatment for both sex groups, indicating decrease of NLvl, with larger decrement in female group. (M: $\mathrm{p}<0.007$ and $F: p<0.0002$ ).

Figure 5 showed the difference of FO Overall Variability (FOVAR) pre and post-treatment for both sex groups, indicating decrease of FO Variability, with female group had larger decrement, although both were considerably significant. (M: $\mathrm{p}<0.008$ and $\mathrm{F}$ : $\mathrm{p}<0.008$ ).

Figure 6 showed the decrease in differences of the energy of Fast F0 Perturbation pre and post-treatment for both sex group, indicating female group had larger decrement. (M: $p<0.05$ and F: $p<0.001$ ).

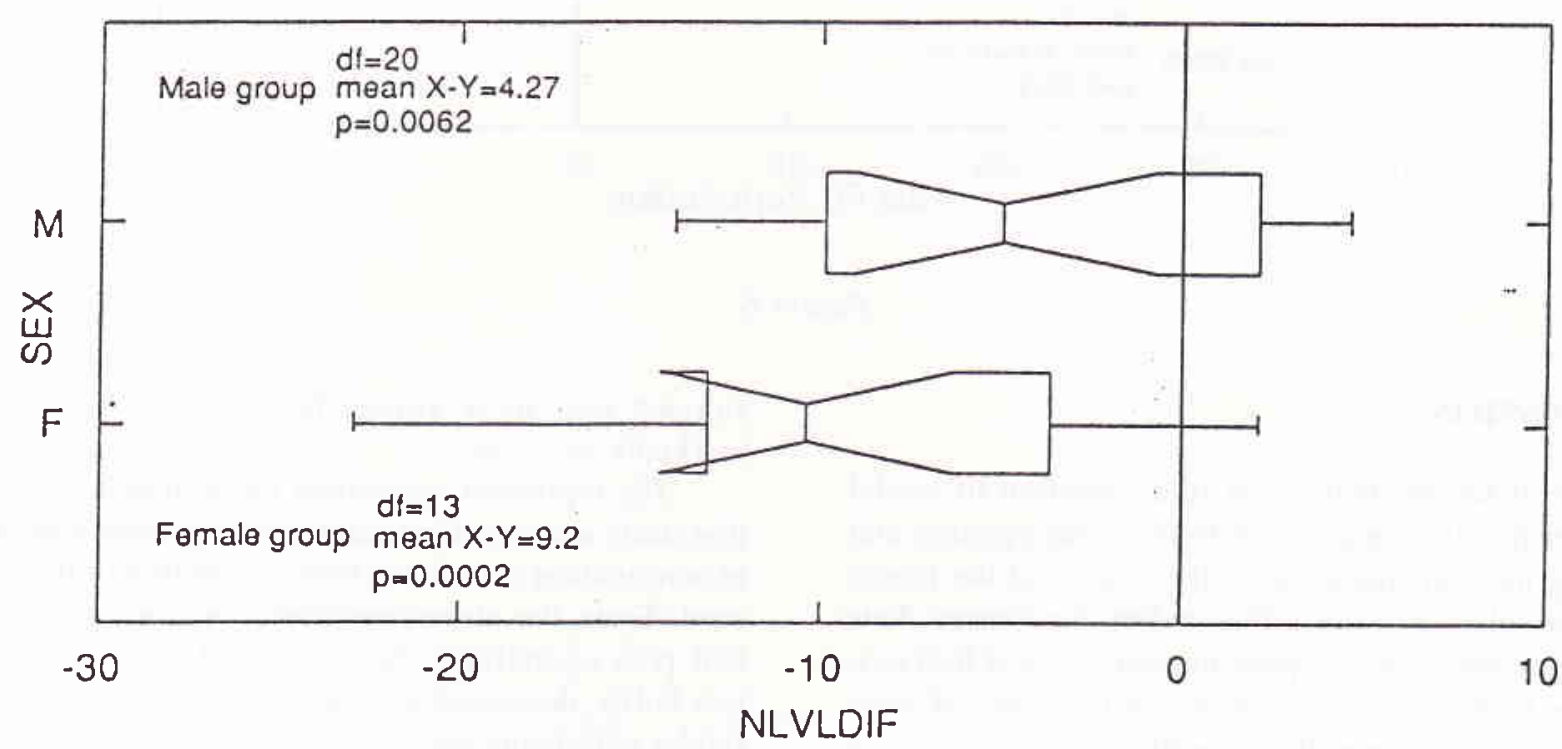

Figure 4

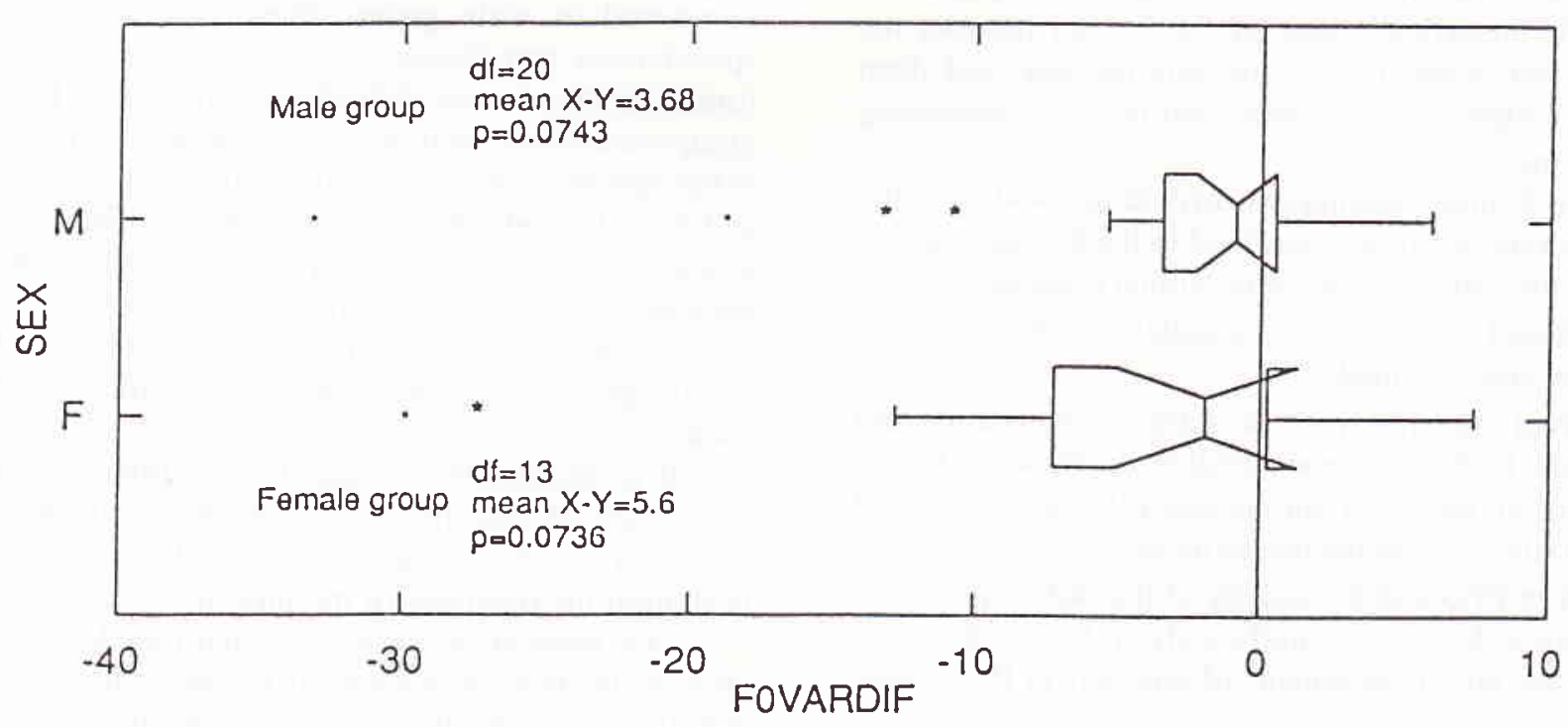

Figure 5 


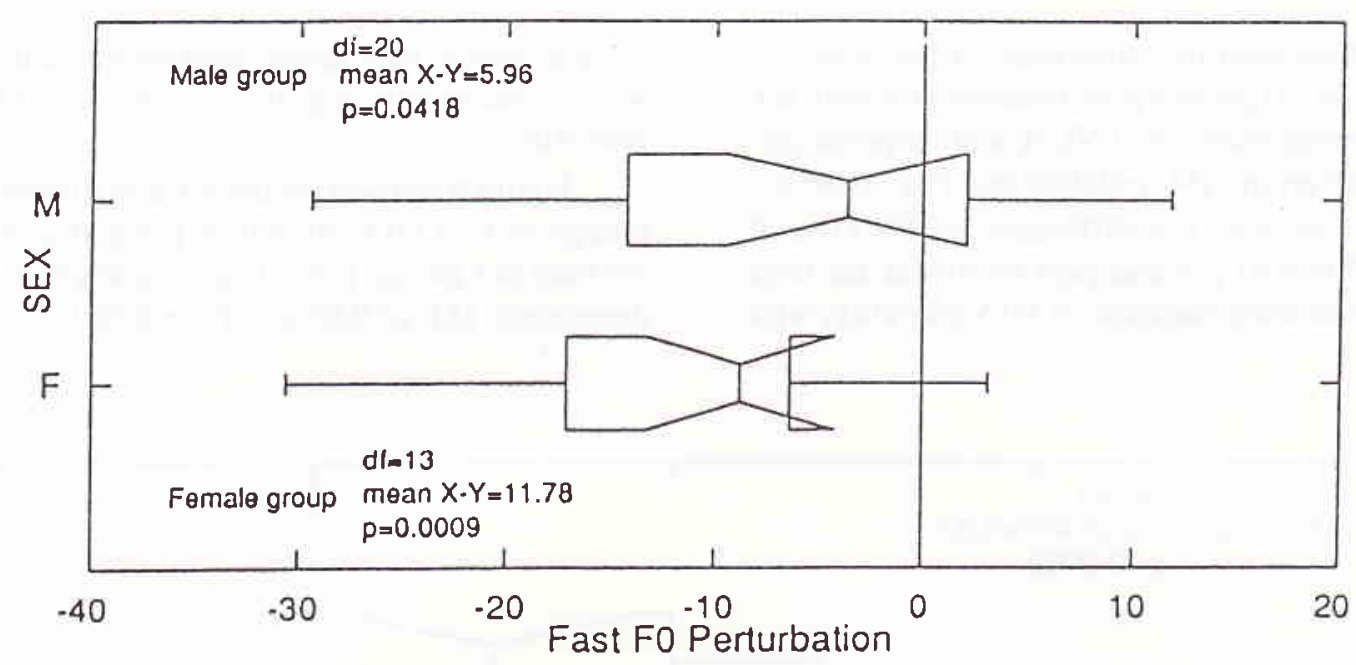

Figure 6

\section{DISCUSSION}

It is well known that vocal fold vibration in modal register involves in addition to the gross opening and closing movements, a wave-like motion of the looser mucose relative to the stiffer underlying tissues. This has led to theoretical approximation of vocal fold motion by mathematical two-mass (or two rows of masses) models, ${ }^{7}$ where the superficial row of masses represent the "cover" and the deeper row the "body". From the mechanical point of view, the five histological layers described by Hirano ${ }^{8}$ can be reclassified into three sections: the cover consisting of the epithelium and the superficial layer of the lamina propria, the transition consisting of the intermediate and deep layers of the lamina propria, and the body consisting of the muscle.

In Reinke's edema or polypoid of vocal cord, the edematous swelling is confined to the Reinke's space, under the superficial layer of lamina propria.

Based on the above calculations, the following results were obtained.

Post operatively, those subjects showed marked increase in $\mathrm{F}_{0}$ with considerable decrease in fractal dimension, although not statistically significant, and $F_{0}$ variability were decreased as well.

The PPQ and the energy of the fast $F_{0}$ perturbation were decreased significantly in both sex group, with had larger decrement of strength in the female group.

From these parameters we considered that the variability, stability and regularity in producing vowels in the $\mathrm{X} Y$ post operative $=\mathrm{X}$, patients $=\mathrm{Y}$ were improved, with higher fundamental frequency, which suggest that their voices become less rough and markedly less breathy.

The treatment modalities for Reinke's edema in this study were sucking and squeezing technique, both in conjugation to omit the bulky condition of the vocal cord. From the above considerations, we speculated that post operatively the vocal fold became thinner, less bulky, decreased in mass-volume of the cord, less flabby with better approximation in adduction.

Although post treatment condition showed a definitive difference compared to pre treatmen, the interesting sequence in the study was that the female group showed higher differences or larger decrements compared to male group. these sequences drew speculations that female vocal fold were shorter in format, or the severity of the disease among the female group were lower, enabling them to a better efficiency of the operative procedure with a better healing process and from the patients point of view, the disciplinary attitude in following doctor's prohibition in the female patients were higher compared to male ones.

These factors seemed to be favourable on the female group, reflecting in a better condition of the vocal cord.

It is reasonable to suggest that current acoustic techniques of quantifying perturbatory evidence in laryngeal waveforms could reliably and cost-effectively support the functions of monitoring.

The present study above mentioned, showed clearly the role of acoustical assessment of voice quality as a tool for monitoring besides the subjective auditory perceptual judgment. The acoustic data analysis is an objective implementation of arithmetics that can be calculated by means of computer program, and can be perform easily. 
The computer calculation of the sustained vowel voice samples of the patients pre and post treatment reveal the improvement of the voice condition of the subjects post operatively in both sex groups.

\section{CONCLUSION}

In this study the acoustical assessment which had been performed pre and post operatively on 35 patients with Reinke's edema as a tool for monitoring, yields some inferences : 1) the post treatment group showed improvement in variability, stability and regularity in producing sustained vowel, with higher $F_{0}$, which suggest their voice become less rough and markedly less breathy. 2) Incessant larger difference and decrements in the female compared to male speakers are reported. These phenomenons indicate that the acoustic analysis system performed is an efficient monitoring tool in post-treatment voice condition, and in speculating the source's alterations.

\section{REFERENCES}

1. Laver J, Hiller S, Beck JM. Acoustic Waveform Perturbation and Voice disorder. J Voice 1992; 6: 115-26.

2. Imaizumi S. Clinical Application of The Acoustic Measurement of Pathological Voice Qualities. Ann Bull RILP 1986; $20: 211-6$.

3. Yonekawa H. A Clinical Study of Reinke's Edema. Auris Nasus Larynx (Tokyo) 1988;15:57-78.

4. Imaizumi S, Gauffin J. Acoustical perceptual characteristics of Pathological Voices : rough, creak, fry, and diplophonia. Arin Bull RILP 1991; 25 : 109-19.

5. Imaizumi $S$, Abdoerrachman $H$, Niimi $S$, Shimura $Y$, and Saida H. Evaluation of vocal controllability by an objectoriented acoustic analysis system. J Acoust Soc Jpn (E) 1994;15(2):113-6.

6. Abdoerrachman $H$, Imaizumi S, Hirose H, Niimi S. Slow and Fast Perturbations in Voice. - A Preliminary Report -. Ann Bull RILP 1993; 1:125-33.

7. Titze IR. The Human vocal cords. A Mathematical model. Part II. Phonetica 1974; $29: 1-21$.

8. Hirano M. Morphological structure of the vocal fold as a vibrator and its variations. Folia Phoniat $1974 ; 26$ : 89-94. 